\title{
PENGARUH RETURN ON ASSET, FINANCIAL LEVERAGE, DAN UKURAN PERUSAHAAN TERHADAPUNDERPRICING PADA PERUSAHAAN YANG MELAKUKAN INITIAL PUBLIC OFFERING (IPO) DI BURSAEFEK INDONESIA
}

\author{
Putu Widhiastina
}

Rida Prihatni

Universitas Negeri Jakarta

\begin{abstract}
This study aimed to determine the influence of The Influence of return on asset, financial leverage, and size of company on underpricing. Underpricing is measured by division the difference between clossing prices and offering price with offering price, return on asset is measured by division net profit with total asset, financial leverage is measured by division total debt with total equity and size of company is mesured with total sales in annual report company. This study took a sample of initial public offering company listed in Indonesia Stock Exchange during the years 2010-2013. The data obtained by purposive sampling techniques and using multiple regression analysis.

Simultaneous hypothesis testing result show that return on asset, financial leverage and company size simultaneously affect the underpricing. The partial hypothesis test result show that retun on asset, financial leverage and company size have a significant affect the underpricing.
\end{abstract}

Keywords: Return On Assets, Financial Leverage, Company Size, Underpricing

\section{PENDAHULUAN}

Seiring dengan semakin
berkembangnya perekonomian sekarang
ini, banyak perusahaan yang berupaya
untuk mengembangkan usahanya dengan
melakukan berbagai cara, diantaranya
yaitu dengan melakukan ekspansi. Bagi
perusahaan yang melakukan ekspansi,
untuk memenuhi kebutuhan ekspansi
diperlukan dana yang tidak sedikit. Dalam
rangka meraih dana untuk ekspansi bisnis,
perusahaan dapat melakukan dengan
berbagai cara salah satunya dengan IPO
(Initial Public Offering). IPO adalah salah
satu cara bagi perusahaan yang sedang
berkembang untuk mendapatkan tambahan

dana dalam rangka pembiayaan dan perkembangan usahanya.

IPO (Initial Public Offering) merupakan pasar perdana bagi suatu perusahaan untuk menawarkan efeknya (saham, obligasi, dan suart-surat berharga lainnya) kepada publik. Bagi suatu perusahaan (Emiten) IPO secara finansial marupakan sarana memperoleh modal guna pengembangan bisnis perusahaan. IPO merupakan sarana untuk memberikan sinyal kepada publik bahwa perusahaan tersebut telah menjalankan keterbukaan dalam pengelolaannya sehingga citra perusahaan dapat meningkat.

IPO biasanya dilakukan perusahaan untuk dapat meningkatkan transparasi 
proses kerja perusahaan yang dapat dipertanggungjawabkan terhadap semua pemangku kepentingan atas kinerja perusahaan tersebut baik investor, pemerintah maupun Bappepam.

Masalah yang sering muncul dari IPO adalah terjadinya Underpricing, yang menunjukan bahwa sebenarnya harga saham pada waktu perdana relatif lebih rendah dibanding saat diperdagangkan di pasar sekunder. Underpricing dapat terjadi karena perusahaan calon Emiten dan penjamin emisi efek secara bersama-sama mengadakan kesepakatan dalam menentukan harga perdana saham namun mereka mempunyai kepentingan yang berbeda.

Kondisi underpricing merugikan untuk perusahaan yang melakukan go public, karena dana yang diperoleh dari publik, karena dana yang diperoleh dari publik tidak maksimum. Terjadinya underpricingpada perusahaan yang pertama kalinya melakukan IPO dipengaruhi oleh bebrapa faktor, diantaranya kondisi informasi yang asimetris ini merupakan salah satu penyebab terjadinya underpricing dimana underwriter yang memiliki lebih banyak informasi menggunakan ketidaktahuan Emiten untukge memperkecil resiko. Dengan demikian akan terjadi underpricing yang berarti bahwa penentuan harga saham di pasar perdana lebih rendah dibanding harga saham di pasar sekunder pada saham yang sama Jurnal IImiah Wahana Akuntansi seperti ukuran perusahaan, retun on asset dan finacial leveage.

Berdasarkan paparan diatas, penulis tertarik untuk melihat apakah faktor reputasi underwriter, reputasi auditor, ukuran perusahaan, Return On Assets (ROA) dan financial leverage dapat mempengaruhi tingkat underpricing pada perusahaan yang melakukan penawaran umum perdana (IPO) di Bursa Efek Indonesia. Dengan dasar tersebut, maka penelitian ini mengambil judul "Pengaruh Return on Asset, Financial Leverage, Ukuran Perusahaan Terhadap Underpricing Pada Perusahaan yang Melakukan Initial Public Offering (IPO) di Bursa Efek Indonesia".

\section{KAJIAN PUSTAKA， KERANGKA PEMIKIRAN, DAN HIPOTESIS}

\section{Pasar Modal}

Definisi pasar modal menurut Tjiptono Darmadji dan Hendy $M$. Fakhruddin (2006) pasar modal (capital market) merupakan pasar untuk berbagai instrumen keuangan jangka panjang yang bisa diperjualbelikan, baik dalam bentuk utang, ekuitas (saham), instrumen derivatif, maupun instrumen lainnya. Pasar modal merupakan sarana pendanaan bagi perusahaan maupun institusi lain (misalnya pemerintah) dan sarana bagi kegiatan berinvestasi. Dengan demikian, pasar modal memfasilitasi berbagai sarana 
dan prasarana kegiatan jual beli dan kegiatan terkait lainnya.

Darmadji (2006) menyebutkan ada beberapa jenis-jenis pasar modal, yaitu:

a. Pasar Perdana (Primary Market)

Pasar perdana adalah jenis pasar pada pasar modal dimana saham dan sekuritas lainnya dijual pertama kali pada masyarakat (penawaran umum) sebelum saham dan sekuritas tersebut dicatatkan di bursa. Kegiatan ini disebut penawaran umum perdana (Initial Public Offering).

Harga saham dipasar perdana ditentukan oleh Emiten dan penjamin emisi (underwriter) berdasarkan faktor-faktor fundamental dan faktor lain yang perlu diidentifikasi. Underwriter selain menentukan harga saham bersama Emiten, juga melakukan proses penjualannya.

b. Pasar Sekunder (Secondary Market)

Pasar sekunder adalah pasar modal dimana saham dan sekuritas lainnya diperjual belikan kepada umum setelah masa penjualan disaham perdana. Harga saham dipasar ini ditentukan oleh permintaan dan penawaran yang dipengaruhi berbagai faktor internal seperti earnings per share (EPS) atau kebijakan deviden dan faktor eksternal seperti kebijakan moneter dan inflasi.

Jurnal IImiah Wahana Akuntansi

\section{Penawaran Umum Perdana}

Penawaran Umum atau sering pula disebut Go Public adalah kegiatan penawaran saham atau efek lainnya yang dilakukan oleh Emiten (perusahaan yang go public) kepada masyarakat berdasarkan tata cara yang diatur oleh UU Pasar Modal dan Peraturan Pelaksanaannya (Sunariyah,2006).

Menurut Sitompul (2000) penjualan saham oleh perusahaan yang dilakukan untuk pertama kali disebut Penawaran Umum atau Initial Public Offering (IPO). Pada penjualan saham ini perusahaan akan menerima uang tunai dan keuntungan dari selisih nilai nominal saham dengan harga saham pada pasar perdana.

Terdapat beberapa keuntungan bagi perusahaan dalam melakukan Penawaran umum saham diantaranya:

a. Dapat memperoleh dana yang relatif besar dan diterima sekaligus (tidak dengan termin-termin).

b. Biaya go public relatif murah.

c. Proses relatif mudah.

d. Pembagian dividen berdasarkan keuntungan.

e. Penyertaaan masyarakat biasanya tidak masuk dalam manajemen.

f. Perusahaan dituntut lebih terbuka, sehingga hal ini dapat memacu perusahaan untuk meningkatkan profesionalisme.

g. Emiten akan lebih dikenal oleh masyarakat (go public merupakan media promosi) secara gratis. 
Disamping terdapat keuntungan, penawaran umum saham juga memiliki beberapa konsekuensi, diantaranya:

a. Keharusan untuk melakukan keterbukaan (full disclosure)

Perusahaan yang terdaftar dibursa saham diharuskan untuk mengungkapkan semua informasi yang perusahaan miliki secara rutin kepada para investor. Namun, level keterbukaan pada saham tentunya berbeda dengan level keterbukaan dengan pemegang hutang (debt holder).Hal ini terkadang membuat pemilik perusahan tidak nyaman, karena perusahaan diharuskan untuk memberitahukan kepada publik perihal gaji dan laporanlaporan keuangan yang seringkali menjadi incaran kritik dari para wartawan.

b. Menyulitkan kinerja manajemen

Pada perusahan publik, kepemilikannya terpisah dari manajemen. Untuk mengawasi kinerja manajemen, pemilik membentuk dewan direksi. Apabila dewan direksi terlalu ketat dalam mengawasi, maka hal ini seringkali menyulitkan kinerja manajemen.

c. Keharusan untuk megikuti peraturan-peraturan pasar modal mengenai kewajiban pelaporan.

d. Kewajiban membayar dividen bila perusahaan mendapatkan laba.

\section{Perusahaan Emiten}

Menurut Otoritas Jasa Keuangan Emiten adalah Pihak yang melakukan Penawaran Umum, yaitu penawaran Efek yang dilakukan oleh Emiten untuk menjual Efek kepada masyarakat berdasarkan tata cara yang diatur dalam peraturan Undang-undang yang berlaku.

Emiten dapat berbentuk orang perseorangan, perusahaan, usaha bersama, asosiasi, atau kelompok yang terorganisasi.

Emiten dapat menawarkan Efek yang berupa surat pengakuan utang, surat berharga komersial, saham, obligasi, tanda bukti utang, Unit Penyertaan kontrak investasi kolektif, kontrak berjangka atas Efek, dan setiap derivatif dari Efek.

\section{Penjamim Emisi (Underwriter)}

$$
\text { Menurut Sunariyah (2004:117) }
$$

penjamin emisi (underwriter) adalah pihak yang telah mengadakan kontrak untuk membeli efek dari Emiten, pihak pengendali yang mempunyai afiliasi dengan Emiten atau telah mengadakan kontrak dengan Emiten, atau pihak pengendali yang mempunyai afiliasi dengan Emiten, untuk menawarkan atau menjual efek melalui suatu penawaran.

Dalam melaksanakan fungsinya, para penjamin emisi melakukan kegiatan antara lain:

a. Membantu Emiten dalam rangka mempersiapkan pernyataan 
pendaftaran berikut dokumen pendukungnya.

b. Memberi konsultasi dibidang keuangan seperti jumlah dan jenis efek yang akan diterbitkan, bursa yang dipilih untuk mencatatkan saham, penentuan jadwal emisi, penunjukkan lembaga penunjang lain, metode pendistribusian dan sebagainya.

c. Melakukan penjaminan terhadap efek yang diemisikan.

d. Melakukan evaluasi terhadap kondisi perusahaan antara lain keuangan, manajemen, pemasaran, produksi, berikut prospeknya.

e. Menentukan harga saham bersamasama Emiten.

\section{Underpricing Saham}

Underpricingmenurut Manurung (2013:23) merupakan kondisi dimana harga penawaran pada saat IPO dinilai lebih rendah secara signifikan dibandingkan harga saham pada saat penutupan hari pertama dipasar sekunder. Selisih harga inilah yang dikenal dengan initial return. Apabila harga saham pada pasar perdana (IPO) lebih rendah dibandingkan dengan harga saham pada pasar sekunder pada hari pertama, maka akan terjadi underpricing. Sebaliknya, apabila harga saat IPO lebih tinggi dibandingkan dengan harga saham pada pasar sekunder pada hari pertama, maka fenomena ini disebut overpricing. Jurnal IImiah Wahana Akuntansi
Fenomena underpricing terjadi karena adanya mispriced dipasar perdana sebagaiakibat adanya ketidakseimbangan informasi antara pihak underwriter dengan pihak Emiten, biasanya disebut asimetri informasi (information asymmetry). Underpricing terjadi karena ex-ante uncertainty harga saham pada saat penawaran perdana. Terdapat beberapa teori yang menjelaskan fenomena underpricing didalam Initial Public Offering (Ritter, 1994) yaitu:

\section{a. TheWinner's CunveHypothesis}

Sebuah pemahaman penting dari underpricing saat IPO adalah penjelasan kutukan pemenang (winner's curve). Hal ini terjadi karena jumlah saham yang ditawarkan dijual pada fixed price, pembatasan permintaan akan menyebabkan permintaan meningkat tanpa dapat diperkirakan sebelumya. Distribusi saham sendiri tidak mengarah kepada terjadinya underpricing, tetapi jika dipasar terdapat investor-investor yang tidak memiliki cukup informasi ini cenderung akan mengalokasikan investasinya pada saham-saham yang yang kurang diinginkan.

Para investor ini menghadapi kutukan pemenang, dimana tanpa disadari mereka dapat memiliki saham yang diinginkan karena para investor yang memiliki informasi lebih banyak memang tidak menginginkan saham-saham tersebut. Dihadapkan pada situasi tersebut, para investor yang tidak memiliki cukup 
informasi hanya akan membeli saham perdana tersebut apabila secara rata-rata tingkat underpricing nya cukup untuk mengimbangi bias dalam alokasi saham baru.

\section{b. The Signaling Hypothesis}

Sekuritas yang underpriced meninggalkan kesan baik bagi investor, hal ini membuka peluang bagi perusahaan dan orang dalam untuk menjual penawaran di masa depan dengan harga lebih tinggi dibandingkan seharusnya.

Pada model ini, perusahaan penerbit sekuritas memiliki informasi rahasia apakah firm value mereka rendah atau tinggi. Dengan memberikan kesan yang baik, bahwa permintaan atas saham tersebut tinggi yang ditandai dengan underpricing, maka diharapkan sekuritas perusahaan dan firm value perusahaan akan naik setelah periode IPO.

\section{c. The Ownership Dispersion Hypothesis}

Penerbit sekuritas dengan sengaja melakukan underpricingsaham mereka untuk menghasilkan kelebihan permintaan sehingga dapat memiliki pemegang saham kecil dalam jumlah yang banyak. Kepemilikan tersebar ini akan meningkatkan likuiditas pasar, dan membuat lebih sulit bagi orang luar untuk masuk kedalam manajemen.

\section{d. The Agency Cost Hypothesis}

Menurut hipotesis ini disebutkan bahwa penjamin emisi mengambil keuntungan dari belum berpengalamannya Jurnal IImiah Wahana Akuntansi perusahaan Emiten(issuer), yaitu dengan cara melakukan underpricingatas penawaran perdana milik Emiten, (Penjelasan ini gagal memasukkan pertimbangan atas efek reputasi underwriter, serta belum lagi dengan penjelasan mengenai adanya kompetisi diantara para penjamin emisi).

$$
\text { Baron (1982) mengemukakan }
$$
bahwa underwritermemiliki informasi yang lebih baik mengenai harga yang tepat bagi sahamsaham baru yang akan diterbitkan. Tujuan dari dilakukannya underpricing adalah karena harga yang lebih rendah dapat memudahkan usaha untuk mendistribusikan saham ke pasar. Dengan melakukan underpricing, penjamin juga dapat mengurangi kemungkinan terjadinya kekurangan pembeli (undersubcription).

Secara implisit hipotesis ini mengindikasikan bahwa seharusnya underpricingtidak terjadi pada perusahaan (issuer) yang juga merupakan penjamin emisi. Namun dari hasil penelitian Muscarella dan Vetsuypens mengemukakan bahwa saham-saham IPO dari penjamin emisi yang melakukan usaha marketing atas saham-sahamnya sendiri, mengalami tingkat underpricingdengan level yang hampir sama seperti saham-saham biasa.

\section{Informasi Akuntansi yang}

Mempengaruhi Underpricing

Menurut Warren (2006) secara umum akuntansi dapat didefinisikan 
sebagai informasi yang menghasilkan

laporan kepada pihak-pihak yang berkepentingan mengenai aktivitas ekonomi dan kondisi perusahaan.

Akuntansi merupakan bahasa perusahaan karena melalui akuntansiinformasi dikomunikasikan kepada pihak-pihak yang berkepentingan. Hal ini menunjukan bahwa informasi menjadi suatu bagian dari proses akuntansi.

Berdasarkan definisi akuntansi tersebut dapat diketahui bahwa informasi yang diperoleh dari aktivitas ekonomi dan kondisi perusahaan itu sendiri. Informasi tersebut disusun dalam betuk laporan akuntansi yang disebut laporan keuangan.

Informasi akuntansi yang digunakan penulis untuk variabel penelitian adalah sebagai berikut:

\section{a. Return On Asset (ROA)}

ROA merupakan salah satu rasio profitabilitas untuk mengetahui tingkat pengembalian saham atas harta yang dimiliki oleh perusahaan. ROAdigunakan untuk mengukur efektivitas perusahaan dalam menghasilkan keuntungan dengan cara memanfaatkan aset yang dimilikinya. Semakin tinggi ROA perusahaan maka akan semakin rendah underpricing karena investor akan menilai kinerja perusahaan lebih baik dan bersedia membeli saham perdananya dengan harga yang lebih tinggi (Subramanyam, 2011).

Calon investor akan mempertimbangkan prosentase Jurnal IImiah Wahana Akuntansi profitabilitas perusahaan sebelum menentukan keputusan investasinya sehingga nilai ketidakpastiannya semakin rendah yang juga akan menurunkan nilai underpricingperusahaan tersebut.

$$
\text { Subramanyam }
$$
menyatakan bahwa ROA dapat diukur dengan menggunakan rumus sebagai berikut:

$$
\text { Return On Assets }=\frac{\text { Earning after tax }}{\text { Total assets }}
$$

\section{b. Financial Leverage (DER)}

Debt to Equity Ratio (DER) merupakan salah satu dari rasio leverage. DER mencerminkan kemampuan perusahaan dalam memenuhi seluruh kewajibannya yang ditujukan oleh beberapa bagian modal sendiri yang digunakan untuk membayar hutang.

DER menunjukan hubungan antara tingkat leverage (penggunaan hutang) dibandingkan modal sendiri perusahaan (Subramanyam, 2011).

DER memeberikan gamabaran tentang beberapa seberapa besar hutanghutang perusahaan dijamin modal sendiri perusahaan yang digunakan sebagai pendanaan usaha. Semakin besar DER menandakan struktur pemodalan usaha lebih banyak memfaatkan hutang-hutang relatif terhadap ekuitas. Semakn besar DER mencerminkan resiko perusahaan yang relatif tinggi (Afifah, 2011).

Subramanyam

(2011:44)

menyatakan bahwa DER dapat diukur 
dengan menggunakan rumus sebagai berikut:

$$
\text { Debt to Equity Ratio }=\frac{\text { Total Debt }}{\text { Total Equity }}
$$

\section{c. Ukuran Perusahaan}

Arta et.all (2011) menyatakan bahwa ukuran perusahaan adalah total asetyang dimiliki suatu perusahaan.

Menurut Mochfoedz (1994) dalam Rahmi (2010), ukuran perusahaan pada dasarnya terbagi dalam tiga kategori:

1. Perusahaan Besar (Large Firm)

Perusahaan yang dikategorikan perusahaan besar biasanya merupakan perusahaan yang telah go publik di pasar modal dan termasuk dalam kategori papan pengembangan satu yang memiliki total aset sekurang-kurangnya Rp200.000.000.000.

2. Perusahaan Menengah (Medium Size)

Perusahaan yang dikategorikan perusahaan menengah biasanya listing di pasar modal papan pengembangan dua dan umumnya memiliki total aset Rp2.000.000.000 s.d. Rp200.000.000.000.

3. Perusahaan Kecil (Small Firm) Perusahaan yang dikategorikan perusahaan kecil merupakan perusahaan yang memiliki total aset kurang dari Rp2.000.000.000 dan biasanya perusahaan kecil ini belum terdaftar di Bursa Efek Indonesia.
Teori critical resource menekankan pada pengendalian oleh pemilik perusahaan terhadap sumber daya perusahaan seperti asset, technology, dan intellectual property sebagai faktor-faktor yang menentukan firm size.

Size perusahaan dapat diukur dengan beberapa proksi: aset (asset), penjualan, jumlah pekerja, dan nilai tambah (value added). Teori teknologi perusahaan yang menekankan skala ekonomis yang timbul dari capital input akan menggunakan asset atau penjualan sebagai pengukur size (Kusuma, 2005).

Ukuran perusahan (company size) secara umum dapat diartikan sebagai suatu perbandingan besar atau kecilnya suatu objek. Ukuran perusahaan menunjukan besar atau kecilnya kekayaan (asset) yang dimiliki suatu perusahaan.

Pengukuran perusahaan bertujuan untuk membedakan secara kuantitatif antara perusahaanbesar (large firm) dengan perusahaan kecil (small firm). Besar kecilnya suatu perusahaan dapat mempengaruhi kemampuan manajemen untuk mengoperasikan perusahaan dengan berbagai situasi dan kondisi yang dihadapinya. Pada akhirnya kemampuan untuk mengoperasikan perusahaan tersebut dapat mempengaruhi pengembalian utang perusahaan (Yulia, 2009).

Ukuran perusahaan dapat dirumuskan dengan:

a. Ukuran Perusahaan $=$ Total Aset 
b. Ukuran Perusahaan $=$ Total Penjualan

c. Ukuran Perusahaan = Jumlah Karyawan

\section{Pengembangan Hipotesis}

ROAmerupakan salah satu rasio profitabilitas untuk mengetahui tingkat pengembalian saham atas harta yang dimiliki oleh perusahaan. Semakin tinggi ROA perusahaan akan semakin rendah underpricingnya.

Semakin besar hutang (DER) maka mencerminkan resiko perusahaan yang relatif tinggi, akibatnya investor cenderung menghindari saham-saham yang memiliki DER yang tinggi. Dengan Demikian semakin tinggi DER maka semakin besar pula tingkat underpricingnya.

Ukuran perusahaanmenunjukkan pengaruh negatif dan signifikan terhadap underpricing. Perusahaan besarperusahaan tersebut telah mencapai tahap kedewasaan dimana dalam tahap ini arus kas perusahaan sudah positif dan dianggap memiliki prospek yang baik dalam jangka waktu yang relatif lama, selain itu juga mencerminkan bahwa perusahaan relatif lebih stabil dan lebih mampu menghasilkan laba dibanding perusahaan dengan total penjualan yang kecil.

Berdasarkan kajian teoritik dan hasil penelitian relevan yang telah dikemukakan di atas maka hipotesis penelitian ini dirumuskan sebagai berikut:
$\mathrm{H}_{1}$ : Return on Asset berpengaruh terhadap underpricing.

$\mathrm{H}_{2}$ : Financial Leverage berpengaruh terhadap underpricing.

$\mathrm{H}_{3}$ : Ukuran Perusahaan berpengaruh terhadap underpricing

$\mathrm{H}_{4}$ : Return on Asset, financial leverage, dan ukuran perusahaan berpengaruh secara bersama-sama terhadap underpricing.

\section{OBJEK DAN METODELOGI PENELITIAN}

Objek penelitian ini adalah perusahaan-perusahaan yang melakukan IPO dan terdaftar di Bursa Efek Indonesia periode 2010-2013. Peneliti membatasi ruang lingkup penelitian ini pada pengaruh return on asset, financial leverage, dan ukuran perusahaanpada indikator underpricing.

Metode yang digunakan dalam penelitian ini menggunakan metode kuantitatif yang menggunakan cara-cara tertentu dalam mengumpulkan, mengolah, dan menganalisis data yang disajikan dan diukur dalam suatu skala numerik atau dalam bentuk angka-angka dengan teknik statistik, kemudian mengambil kesimpulan secara generalisasi untuk membuktikan adanya pengaruh dalam penelitian ini.

\section{Definisi Operasionalisasi Variabel}

\section{Underpricing Saham}

Underpricing saham dicerminkan dari initial return dengan menghitung

Jurnal IImiah Wahana Akuntansi 
selisih antara harga penawaran umum perdana (offering price) dengan harga jual saham di pasar sekunder pada penutupan hari pertama (closing price).

Penghitungan Initial Returndalam penelitian ini menggunakan rumus dalam Tandelilin (2001), yaitu:

$$
\begin{aligned}
& \text { Initial Return } \\
& =\frac{\text { Closing Price }- \text { Offering Price }}{\text { Offering Price }} \times 100 \%
\end{aligned}
$$

\section{Return On Asset (ROA)}

ROA merupakan perkalian antara faktor margin laba dengan perputaran total aset. Margin laba menunjukkan kemampuan memperoleh laba bersih dari setiap penjualan yang diciptakan oleh perusahaan, sedangkan perputaran total aset menunjukkan seberapa jauh perusahaan mampu menciptakan penjualan dari total aset yang dimilikinya (Brigham dan Houston, 2006: 114). Apabila salah satu faktor tersebut meningkat (atau keduanya), maka ROA juga akan meningkat. Apabila ROA meningkat, berarti profitabilitas perusahaan juga meningkat, sehingga dampaknya adalah peningkatan profitabilitas yang dinikmati oleh pemegang saham.

Penghitungan ROA dalam penelitianini menggunakan rumus dalam Brigham dan Houston (2006:115) sebagai berikut:

$$
\text { Return On Assets }=\frac{\text { Laba Bersi }}{\text { Total Aset }}
$$

\section{Debt to Equity Ratio (DER)}

DER adalah rasio yang mengukur sejauhmana besarnya utang yang ditutupi oleh modal sendiri. Debt to Equity Ratio (DER) adalah perbandingan antara jumlah total hutang terhadap total equity.

Penghitungan DER dalam penelitian ini menggunakan rumus dalam Subramanyam (2011:44) yaitu:

$$
\text { Debt to Equity Ratio }=\frac{\text { Total Debt }}{\text { Total Equity }}
$$

\section{Ukuran Perusahaan}

Ukuran perusahaan dapat diukur dengan menggunakan total penjualan, pendapatan atau modal dari perusahaan tersebut yang dapat dilihat dari laporan keuangan yang dibuat oleh perusahaan tersebut. Total penjualan dapat digunakan untuk menunjukkan seberapakah besar kecilnya suatu perusahaan, apabila suatu perusahaan memiliki total penjualan besar maka perusahaan tersebut telah terbilang memiliki prospek yang baik dan lebih mampu menghasilkan laba daripada perusahaan dengan total penjualanannya kecil (Hadri Kusuma, 2005).

Pada penelitian ini ukuran perusahaan menggunakan log total penjualan, dalam Chen (2005) yang dimaksudkan untuk menghindari masalah data natural yang berdistribusi normal.

\section{Metode Pengumpulan Data}

Metode yang digunakan dalam penelitian ini menggunakan metode 
kuantitatif yang menggunakan cara-cara tertentu dalam mengumpulkan, mengolah, dan menganalisis data yang disajikan dandiukur dalam suatu skala numerik atau dalam bentuk angka-angka dengan teknik statistik, kemudian mengambil kesimpulan secara generalisasi untuk membuktikan adanya pengaruh dalam penelitian ini.

\section{Teknik Analisis Data}

Metode analisis data yang digunakan dalam penelitian ini adalah metode analisis statistik dengan menggunakan SPSS.

\section{PEMBAHASAN}

\section{Pengaruh Return On Asset Terhadap}

\section{Underpricing}

Hipotesis pertama yang menyatakan bahwa Return on Asset (ROA) berpengaruh signifikan terhadap underpricing diterima dengan adanya hasil uji penelitian yang telah dilakukan. Penelitian ini menghasilkan bukti bahwa ROA memiliki pengaruh signifikan dengan underpricing.

Berdasarkan hasil data penelitian yang dihasilkan bahwa ROA berhubungan positif dengan underpricing. Dimana semakin tinggi ROA semakin tinggi pula tingkat underpricing. Hasil penelitian ini sejalan dengan penelitian yang dilakukan oleh Prastica (2012) yang menyatakan bahwa ROA memiliki pengaruh signifikan dan hubungan positif terhadap underpricing. Jurnal IImiah Wahana Akuntansi
ROA merupakan salah satu rasio profitabilitas untuk mengetahui tingkat pengembalian saham atas harta yang dimiliki oleh perusahaan. ROA digunakan untuk mengukur efektivitas perusahaan dalam menghasilkan keuntungan dengan cara memanfaatkan aset yang dimilikinya (Subramanyam, 2011). Calon investor akan mempertimbangkan prosentase profitabilitas perusahaan sebelum menentukan keputusan investasinya sehingga nilai ketidakpastiannya semakin rendah yang juga akan menurunkan nilai underpricing perusahaan tersebut.

ROA merupakan pertimbangan penting bagi investor ketika akan membeli saham. ROA menunjukkan keefisienan perusahaan dalam memanfaatkan aset yang ada untuk menghasilkan laba, sehingga semakin tinggi rasio ini menggambarkan tingkat efisiensi yang tinggi dari perusahaan. Bila efisiensinya tinggi maka diharapkan perusahaan tersebut menguntungkan (dari segi pendapiatan). Keadaan ini tentu saja menarik minat investor untuk membeli saham perusahaan, sehingga harga sahamnya pun akan meningkat.

Hal tersebutlah yang membuat ROA menpunyai hubungan positif dan signifikan terhadap underpricing, semakin tinggi ROA semakin tinggi tingkat underpricing karena dengan ROA yang tinggi saham perusahaan tersebut banyak diminati oleh investor, karena perusahaan tersebut dinilai efisien dan dapat 
menguntunkan investor sehingga semakin banyak penawaran atas sahamtersebut. Maka akan semakin naik harga sahamnya yang mengakibatkan semakin tinggi pula tingkat underpricingnya.

Hal tersebut tercermin pada PT. Skybee, Tbk yang menerbitkan saham perdananya pada tahun dengan ROA 0,595 dan mempunyai tingkat underpricing 0,493. Disisis lain perusahaan dengan PT. PP, Tbk yang menerbitkan saham perdananya pada tahun 2010 mempunyai nilai ROA yang lebih kecil sebesar 0,0,37 dan mempunyai nilai underpricing yang kecil pula yaitu sebesar 0,036. Berdasarkan uraian tersebut dapat disimpukan bahwa investor dalam berinvestasi mempertimbangkan nilai ROA perusahaan yang akan berdampak pada tingkat underpricing perusahaan tersebut.

Hasil penelitian tersebut mendukung the winner's curve hypothesis menyatakanjumlah saham yang ditawarkan dijual pada fixed price dibatasi, dengan pembatasan permintaan akan menyebabkan permintaan meningkat tanpa dapat diperkirakan sebelumya. Informasi keuangan yang diketahui oleh investor salah satunya dengan melihat ROA yang tinggi akan mengakibatkan permintaan atas saham yang cukup tinggi namun jumlah saham yang beredar terbatas sehingga terjadi kenaikan harga saham yang menyebabkan underpricing. Disamping itu adanya information Jurnal IImiah Wahana Akuntansi asymmetry antara emiten dan pihak underwriter dimana pihak emiten memiliki informasi lebih sedikit dan pihak underwriter menggunakan ketidaktahuan emiten untuk memperkecil resiko sebagai penjamin emisi.

Namun hasil penelitian ini tidak sejalan dengan hasil penelitian yang dilakukan oleh Wijayanto (2010) dan Mahendra (2013) yang membuktikan bahwa ROA tidak memiliki pengaruh signifikan dengan underpricing.

\section{Pengaruh Debt to Equity Ratio Terhadap Underpricing.}

Hipotesis kedua yang menyatakan bahwa Debt to Equity Ratio (DER) berpengaruh terhadap underpricing diterima dengan adanya hasil uji penelitian yang telah dilakukan. Penelitian ini menghasilkan bukti bahwa DER memiliki pengaruh signifikan dengan underpricing.

Berdasarkan hasil data penelitian yang dihasilkan bahwa DER berhungan positif dengan underpricing. Dimana semakin tinggi DER semakin tinggi pula tingkat underpricing. Hasil penelitian ini sejalan dengan penelitian yang dilakukan oleh Idriyanti (2013) dan Wulandari (2011) yang menyatakan bahwa DER terhadap underpricing memiliki hubungan yang positif dan memiliki pengaruh signifikan terhadap underpricing.

DER mencerminkan kemampuan perusahaan dalam memenuhi seluruh kewajibannya yang ditujukan oleh 
beberapa bagian modal sendiri yang digunakan untuk membayar hutang. DER menunjukan hubungan antara tingkat leverage (penggunaan hutang) dibandingkan modal sendiri perusahaan (Subramanyam,2011). Perusahaan dengan DER yang tinggi akan memiliki resiko yang lebih tinggi dikarenakan total hutang yang tinggi pula. Sebaliknya dengan perusahaan yang memiliki DER yang rendah, memiliki resiko yang rendah pula karena total hutang yang dimiliki rendah dibandingkan dengan modal.

Hal tersebut berarti DER menunjukkan risiko suatu perusahaan sehingga berdampak pada ketidakpastian. Hal ini dapat mengurangi minat investor untuk membeli saham tersebut. DER yang tinggi menunjukkan risiko finansial atau risiko kegagalan perusahaan untuk mengembalikan pinjaman akan semakin tinggi, dan sebaliknya.

Hal tersebut tercermin pada PT. Bank Sinarmas, Tbk yang menerbitkan saham perdananya pada tahun 2010 melakukan yang mempunyai nilai DER sebesar 11,323 dengan tingkat underpricing sebesar 0,673 sedangkan disisi lain terdapat nilai DER yang lebih kecil pada PT. Semen Baturaja, Tbk yang menerbitkan saham perdanya pada tahun 2013 mempunyai nilai DER yang lebih kecil sebesar 0,099 dengan tingkat underpricing yang kecil pula sebesar 0,018. Berdasarkan uraian tersebut dapat disimpulkan bahwa investor dalam Jurnal IImiah Wahana Akuntansi mengambil keputusan untuk berinvestasi mempertimbangkan nilai DER yang terbukti berdampak terhadap tingkat underpricing.

Hasil penelitian tersebut mendukung exante uncertainty theory atau ketidakpastian informasi yang ditunjukan oleh DER perusahaan yang tinggi mengakibatkan perusahaan tinggi nya tingkat underpricing pada saham perusahaan pasa saat IPO. Para investor dalam melakukan keputusan investasi akan mempertimbangkan nilai DER perusahaan, dan perusahaan yang mempunyai nilai DER yang tinggi akan lebih cenderung menggunakan dana hasil IPO untuk membayar hutangnya daripada untuk kegiatan investasi guna ekspansi baru. Oleh sebab itu tingkat ketidakpastiannya akan semakin tinggi dan menyebabkan nilai underpricing akan semakin tinggi pula.

Namun hasil penelitian ini tidak sejalan dengan hasil penelitian yang dilakukan oleh Ratna (2013) dan Anggita (2013) yang membuktikan bahwa DER tidak memiliki hubungan signifikan dengan underpricing.

\section{Pengaruh Ukuran Perusahaan (SIZE) TerhadapUnderpricing.}

Hipotesis ketiga yang menyatakan bahwa ukuran perusahaan berpengaruh terhadap underpricing diterima dengan adanya hasil uji penelitian yang telah dilakukan. Penelitian ini menghasilkan 
bukti bahwa ukuran perusahaan memiliki pengaruh signifikan dengan underpricing .

Berdasarkan hasil data penelitian yang dihasilkan bahwa ukuran perusahaan hubungan negatif terhadap tingkat underpricing, dimana setiap kenaikan ukuran perusahaan maka diikuti dengan menurunnya tingkat underpricing. Hasil penelitian ini sejalan dengan penelitian yang dilakukan oleh Mahendra (2013) yang menyatakan bahwa ukuran perusahaan memiliki hubungan negatif dan signifikan dengan underpricing.

Ukuran perusahan (company size) secara umum dapat diartikan sebagai suatu perbandingan besar atau kecilnya suatu objek. Ukuran perusahaan menunjukan besar atau kecilnya kekayaan, jumlah penjualan dan jumlah karyawan yang dimiliki suatu perusahaan. Pengukuran perusahaan bertujuan untuk membedakan secara kuantitatif antara perusahaan besar (large firm) dengan perusahaan kecil (small firm). Besar kecilnya suatu perusahaan dapat mempengaruhi kemampuan manajemen untuk mengoperasikan perusahaan dengan berbagai situasi dan kondisi yang dihadapinya (Yulia,2009).

Berarti bahwa investor dalam melakukan keputusan investasi memperhatikan faktor ukuran perusahaan investor memiliki kecenderungan menilai positif persahaan yang memiliki ukuran besar yang dalam penelitian ini digambarkan melalui total penjualan.
Hal tersebut tersebut tercermin pada PT. Dharma Satya Nusantara, Tbk yang menerbitkan saham perdananya pada tahun 2013, perushaan ini mempunyai total penjualan yang tinggi yaitu sebesar Rp3.842.182.000.000 dengan tingkatunderpricingsebesar 0,11 sedangkan disisi PT. Gading Development, Tbk yang menerbitkan saham perdanya pada tahun 2010 memiliki total penjualan yang lebh kecil yaitu sebesar Rp6.842.491.481 dengan tingkat underpricinglebih tinggi sebesar 0,695. Beradasrkan uraian teesebut dapat disimpulkan bahwa investor dalam berinvestasi mempertimbnagkan faktor ukuran perusahaan yang tecermin pada total penjualan yang berdampak terdampak tingkat underpricing.

Hal tersebut mendukung exante uncertainty theory Secara teoritis perusahaan yang lebih besar mempunyai kepastian yang lebih besar darpada perusahaan kecil sehingga akan mengurangi tingkat ketidakpastian mengenai prospek perusahaan kedepan. Hal tersebut dapat membantu investor memprediksi resiko yang mungkin terjadi jika investor berinvestasi pada perusahaan itu. Perusahaan besar pada umumnya lebih dikenal oleh masyarakat daripada perusahaan kecil karena informasi mengenai perusahaan besar lebih banyak dan lebih mudah diperoleh oleh investor dibandingkan dengan perusahan kecil. Sehingga ukuran perusahaan 
mempengaruhi tingkat underpicing pada perusahaan.

Namun hasil penelitian ini tidak sejalan dengan hasil penelitian yang dilakukan oleh Prastica (2012) dan Safitri (2013) yang menyatakan bahwa ukuran perusahaan tidak memiliki pengaruh signifikan dengan underpricing.

\section{Pengaruh ROA, DER, dan Ukuran}

\section{PerusahaanTerhadap Underpricing.}

Berdasarkan uji stimultan (uji F), variable-variabel independen (ROA, DER, danukuran perusahaan) secara bersamasama atau simultan berpengaruh signifikan terhadap underpricing. Dengan melihat hasil penelitian tersebut maka dapat disimpulkan bahwa ROA, DER, danukuran perusahaan menjelaskan atau mempengaruhi underpricing .

\section{Underpricingmenurut}

Adler manurung (2013:23) merupakan kondisi dimana harga penawaran pada saat IPO dinilai lebih rendag secara signifikan dibandingkan harga saham pada saat penutupan hari pertama dipasar sekunder. Selisih harga inilah yang dikenal dengan initial return. Apabila harga saham pada pasar perdana (IPO) lebih rendah dibandingkan dengan harga saham pada pasar sekunder pada hari pertama, maka akan terjadi underpricing.

Fenomena underpricing terjadi karena adanya mispriced dipasar perdana sebagaiakibat adanya ketidakseimbangan informasi antara pihak underwriter dengan Jurnal IImiah Wahana Akuntansi pihak emiten, biasanya disebut asimetri informasi (information asymmetry). Sebagai pihak yang membutuhkan dana, emiten menginginkan harga perdana yang lebih tinggi, dilain pihak, underwriter sebagai penjamin emisi menginginkan harga yang lebih rendah demi meminimalkan resiko yang ditanggungnya. Pihak underwriter kemungkinan mempunyai informasi lebih banyak dibanding pihak emiten. Kondisi asimetri informasi inilah yang menyebabkan terjadinya underpricing, dimana underwriter merupakan pihak yang memiliki banyak informasi dan menggunakan ketidaktahuan emiten untuk memperkecil resiko.

Dengan melihat besarnya ROA perusahaan, investor dapat mengukur efektivitas perusahaan dalam menghasilkan keuntungan dengan cara memanfaatkan aset yang dimilikinya. ROA merupakan pertimbangan penting bagi investor ketika akan membeli saham. ROA menunjukkan keefisienan perusahaan dalam memanfaatkan aset yang ada untuk menghasilkan laba, sehingga semakin tinggi rasio ini menggambarkan tingkat efisiensi yang tinggi dari perusahaan. Bila efisiensinya tinggi maka diharapkan perusahaan tersebut menguntungkan (dari segi pendapatan), sehingga makin diminati oleh investor namun saham yang di tawarkan oleh perusahaan IPO terbatas, hal tersebut 
mempengaruhi tingkat underpricing terhadap saham perusahaan tersebut.

Debt to Equity Ratio (DER) menunjukkan risiko suatu perusahaan sehingga berdampak pada ketidakpastian. Hal ini dapat mengurangi minat investor untuk membeli saham tersebut. DER yang tinggi menunjukkan risiko finansial atau risiko kegagalan perusahaan untuk mengembalikan pinjaman akan semakin tinggi, dan sebaliknya. Para investor dalam melakukan keputusan investasi akan mempertimbangkan nilai DER perusahaan. DER menunjukan hubungan antara tingkat leverage (penggunaan hutang) dibandingkan modal sendiri perusahaan (Subramanyam, 2011).

Perusahaan dengan DER yang tinggi akan memiliki resiko yang lebih tinggi dikarenakan total hutang yang tinggi pula. Sebaliknya dengan perusahaan yang memiliki DER yang rendah, memiliki resiko yang rendah pula karena total hutang yang dimiliki rendah dibandingkan dengan modal. Karena ketidakpastian yang digambarkan oleh DER tersebut berpengaruh terhadap tingkat underpricing saham pada saaat IPO.

Ukuran perusahaan menunjukan besar atau kecilnya kekayaan, jumlah penjualan dan jumlah karyawan yang dimiliki suatu perusahaan. Pengukuran perusahaan bertujuan untuk membedakan secara kuantitatif antara perusahaan besar (large firm) dengan perusahaan kecil (small firm). Besar kecilnya suatu Jurnal IImiah Wahana Akuntansi perusahaan dapat mempengaruhi kemampuan manajemen untuk mengoperasikan perusahaan dengan berbagai situasi dan kondisi yang dihadapinya (Yulia, 2009). Hal tersebut bearati bahwa investor dalam melakukan keputusan investasi memperhatikan faktor ukuran perusahaan investor memiliki kecenderungan menilai positif persahaan yang memiliki ukuran besar yang dalam penelitian ini digambarkan melalui total penjualan. Secara teoritis perusahaan yang lebih besar mempunyai kepastian yang lebih besar darpada perusahaan kecil sehingga akan mengurangi tingkat ketidakpastian mengenai prospek perusahaan kedepan. Hal tersebut dapat membantu investor memprediksi resiko yang mungkin terjadi jika investor berinvestasi pada perusahaan itu. Seiring berkurangnya ketidakpastian maka berpengaruh terhadap tingkat underpricing saham pada saat IPO.

\section{KESIMPULAN， IMPLIKASI， DAN SARAN}

\section{Kesimpulan}

Berdasarkan hasil analisis data dan pembahasan yang telah dilakukan maka dapat ditarik kesimpulan sebagai berikut:

1. Return On Asset berpengaruh signifikan dan hubungan positif denganunderpricing. Semakin tinggi Return On Asset semakin tinggi pula tingkat underpricing. 
2. Debt to Equity Ratio berpengaruh signifikan dan hubungan positif dengan underpricing. Semakin tinggi Debt to Equity Ratio semakin tinggi pula tingkat underpricing.

3. Perusahaan berpengaruh signifikan dan hubungan negatif dengan underpricing. Setiap kenaikan ukuran perusahaan maka diikuti dengan menurunnya tingkat underpricing

4. Return on Asset, Debt to Equity Ratio, danukuran perusahaan secara simultan berpengaruh signifikan terhadap underpricing.

\section{Implikasi}

Emiten sebagai pihak yang membutuhkan dana sebaiknya berusaha memperoleh harga saham perdana yang sewajarnya, dengan lebih mengenal dan mengetahui informasi akuntansi yang berkaitan dengan perusahaan, sehingga menguntungkan pihak lainnya. Karena apabila harga saham perdana yang di tetapkan tidak sesuai maka akan terjadi underpricing yang merugikan emiten. Akibatnya perusahaan tidak dapat memperoleh dana yang maksimum dari pelaksanaan IPO.

Sebelum investor yang akan melakukan investasi pada perusahaan yang melakukan IPO sebaiknya mempertimbangkan faktor-faktor yang telah terbukti mempengaruhi tingkat underpricing seperti Return On Asset, Jurnal IImiah Wahana Akuntansi
Debt to Equity Ratio, dan ukuran perusahaan sehingga dapat mengoptimalkan return yang diperoleh dan meminimalkan resiko investasi.

Return on Assetdapat memberikan informasi kepada investor mengenai bagaimana keefisienan perusahaan dalam memanfaatkan aset yang ada untuk menghasilkan laba.

Debt to Equity Ratio investor dapat memberikan informasi kepada investor mengenai kemampuan perusahaan dalam memenuhi seluruh kewajibannya yang ditujukan oleh beberapa bagian modal sendiri yang digunakan untuk membayar hutang dan melihat dari ukuran persahaan. Investor dapat melihat besar atau kecilnya kekayaan, jumlah penjualan dan jumlah karyawan yang dimiliki suatu perusahaan. Pengukuran perusahaan bertujuan untuk membedakan secara kuantitatif antara perusahaan besar (large firm) dengan perusahaan kecil (small firm). Besar kecilnya suatu perusahaan dapat mempengaruhi kemampuan manajemen untuk mengoperasikan perusahaan dengan berbagai situasi dan kondisi yang dihadapinya.

Selain ROA, DER, dan ukuran perusahaan investor juga dapat mempertimbangkan faktor-faktor lain yang mempengaruhi underpricing seperti return on investment, return on equity, reputasi underwriter, reputasi auditor, umur perusahaan, jumlah saham yang ditawarkan, latar belakang industri, 
earning per share. Dengan mengkombinasikan faktor-faktor tersebut, investor dapat memperkecil resiko seminimal mungkin dan menghasilkan return secara maksimal atas langkah investasinya.

\section{Saran}

Berdasarkan hasil penelitian maka saran yang dapat diberikan untuk penelitian berikutnya adalah:

1. Penelitian selanjutnya diharapkan dapat memperpanjang periode pengamatan, agar memperoleh sampel yang lebih banyak sehingga dapat memperoleh distribusi data yang lebih baik.
2. Peneliti selanjutnya diharapkan dapat menambahkan variabel informasi akuntansi dan non akuntansi, serta melakukan penelitian dengan variabel-variabel makroekonomi seperti inflasi, tingkat suku bunga yang berpotensi mempengaruhi kondisi pasar saham pada saat IPO dilakukan.

3. Diharapkan peneliti selanjutnya melakukan penelitian terhadap performa perusahaan setelah IPO dan meneliti kinerja jangka panjang saham perusahaan yang mengalami underpricing dan overpricing. 


\section{DAFTAR PUSTAKA}

Asnawi, Said Kelana., dan Wijaya Chandra. Riset Keuangan: Pengujian-Pengujian Empiris. Jakarta: Gramedia Pustaka Utama, 2005.

Brigham dan Houston. Dasar-Dasar Manajemen Keuangan. Edisi sebelas. Jakarta: Salemba Empat, 2010.

Cal S Warren., James M Reeve., dan Philip E Fees. Pengantar Akuntansi. Buku Satu. Edisi dua. Jakarta: Salemba Empat, 2006.

Ghozali, Imam. Aplikasi Analisis Multivariate Dengan Program SPSS. Semarang: Badan Penerbit Universitas Diponegoro, 2011.

Gumanti, Tatang. Manajemen Investasi: Konsep, Teori dan Aplikasi. Edisi satu. Jakarta: Mitra Wacana Media, 2007.

Hartono, Jogiyanto. Terori Portofolio dan analisis investasi. Edisi Lima. Yogyakarta: BPFE, 2009.

Indriyanti, Isti. Pengaruh DER, ROI, Current Ratio dan Rata- Rata Kurs Terhadap Underpricing pada IPO. Jurnal Riset Sains Indonesia Vol. 4 Tahun 2013.

John J. Wild. Analisis Laporan Keuangan. Buku satu. Edisi.delapan.Jakarta: Salemba Empat, 2005.

Kuncoro, Mudrajad. Metode Kuantitatif: Teori dan Aplikasi Untuk Bisnis dan Ekonomi. Edisi Keempat. Yogyakarta: Unit Penerbit dan Percetakan Sekolah Tinggi Ilmu Manajemen YKPN.

Mahendra, Ayu Made. Pengaruh Ukuran Perusahaan, ROA, Fiancial Leverage pada Tingkat Underpricing pada Saat Penawaran Saham Perdana di BEI. E Jurnal Akuntansi UDAYANA Vol. 4 No. 1 Tahun 2013.
Ratna, Anggita. Analisis Pengaruh Informasi Keuangan dan Non Keuangan serta Ekonomi Makro Terhadap Underpricing pada Perusahaan Ketika IPO. Jurnal Buletin Studi Ekonomi Vol. 18 No. 2 Tahun 2013.

Safitri, Anggita Tety. Asimetri Informasi dan Underpricing. Jurnal Dinamika Manajemen Vol. 4 No. 1 Tahun 2013.

Sarjono, Haryadi, dan Julianita, Winda. SPSS vs LISREL: Sebuah Pengantar, Aplikasi Untuk Riset. Jakarta: Salemba Empat, 2011.

Sitompul, Asril. Pasar Modal (Penawaran Umum dan Permasalahannya). Bandung: PT Citra Aditya Bakti, 2000.

Situmorang, Paulus. Pengantar Pasar Modal. Edisi Pertama. Jakarta: Mitra Wacana Media, 2008.

Subramanyam dan John J. Wild; K.R. Analisis Laporan Keuanga. Edisi Kedelapan. Buku Dua. Jakarta: Salemba Empat, 2011.

Sunariyah. Pengantar Pengetahuan Pasar Modal. Edisi Keempat.Yogyakarta: UPP AMP YKPN, 2004.

Tandeilin, Eduardus. Analisis Investasi dan Manajemen Portofolio, Edisi Pertama, Yogyakarta: BPFE, 2001.

Tjiptono Darmadji dan Hendy $M$ Fakhruddin. Pasar Modal di Indonesia: Pendekatan Tanya Jawab, Edisi Kedua, Jakarta: Salemba Empat, 2006.

Wulandari, Afifah. Analisis Faktor-faktor yang Mempengaruhi Tingkat Uderpricing pada Penawaran Umum Perdan (IPO) pada Perusahaan Go Public Tahun 20062010. Jurnal Akuntansi dan auduting UNDIP Vol 1 Tahun 2011.

Wijayanto, Andhi. 2010. Analisis Pengaruh ROA, EPS, Financial

Jurnal IImiah Wahana Akuntansi 
Leverage, Proceed Terhadap Initial

Return. Jurnal Dinamika

Manajemen Vol 1 Tahun 2010.

Prastica, Yurena. Faktor-faktor yang mempengaruhi tingkat underpricing pada saat penawaran umum perdana. Jurnal Mahasiswa Akuntansi Vol 1, No. 2 Tahun 2012. http://www.idx.co.id/index.html(diakses tanggal 15 Februari, 2015) www. e-bursa.com (diakses tanggal 19 Februari, 2015.

http://www.ojk.go.id/emiten-danperusahaan-publik(diakses tanggal 21 Februari,2015.

http://finance.yahoo.com(diakses tanggal 4 April

2015) 
